Publisher: Taylor \& Francis

Journal: Archives of Agronomy and Soil Science

DOI: $10.1080 / 03650340.2015 .1093622$

\title{
A glass house trial to investigate the impact of water treatment sludge and green waste compost to enhance the revegetation of contaminated sites
}

\author{
Biola Kazeem Badmos ${ }^{\mathrm{a}}$, Ruben Sakrabani ${ }^{\mathrm{b} *}$, Richard Lord
}

${ }^{a}$ Civil Engineering, Kwame Nkrumah University of Science and Technology, Kumasi, Ghana, ${ }^{\mathrm{b}}$ School of Energy, Environment and Agrifood, Cranfield University, Cranfield, United Kingdom,

${ }^{3}$ Civil and Environmental Engineering, University of Strathclyde, Glasgow, United Kingdom

Corresponding author. Email: r.sakrabani@cranfield.ac.uk

\begin{abstract}
This study investigated the use of waste amendments (green waste compost and water treatment sludge cake) in improving the nutrient and revegetation status of contaminated soil obtained from a former industrial site that has heavy metal and hydrocarbon contamination. The waste amendments were mixed with the contaminated soil at application rates equivalent to 90 and $180 \mathrm{t} \mathrm{ha}^{-1}$ (wet weight) and placed in plastic pots. The unamended soil serves as the control. Reed canary grass and white mustard were allowed to grow on the amended and unamended contaminated soil in the glass house. After a 30 day growth period, soil nutrients status were observed and found higher in the amended contaminated soil than the control. In the amended soil, organic matter, total nitrogen, total potassium and soil nitrate were highest in contaminated soil amended with green waste compost at $180 \mathrm{t} \mathrm{ha}^{-1}$ and lowest in
\end{abstract}


contaminated soil amended with water treatment sludge cake at $90 \mathrm{t} \mathrm{ha}^{-1}$. Above ground dry mass of reed canary grass and white mustard grown on amended contaminated soil increased by $120-222 \%$ and $130-337 \%$ respectively as compared to the control showing that improved fertility of contaminated soils thereafter, enhanced revegetation.

Keywords: contaminated land; green waste compost; water treatment sludge; reed canary grass; white mustard

\section{Introduction}

Waste materials usage as soil amendments is becoming popular because they improve soil properties, thus enhancing vegetation growth. Applications of waste amendments on agricultural, degraded and contaminated lands have been reported. Revegetating contaminated sites improves biological and physical properties of contaminated sites thus increasing nutrient level, organic matter and CEC (Norland and Veith 1995). Vegetation helps to prevent migration of contaminants and it break pathways of pollutant linkages by restricting the movement of water and gas and preventing dust from blowing off contaminated surfaces (Nathanail and Bardos 2004). The survival rates of bacteria or symbiotic fungi which have the ability to degrade toxic chemicals are increased by vegetation availability (Harris 1996). Soil amendments help to improve soil physico-chemical properties. They improve the activities of soil organisms and helps in immobilization of soil contaminants. However, they may inhibit vegetation growth when not properly used. Several amendments that have been applied in restoration/revegetation processes including, for example, green waste compost (Lord et al. 2007; 2010; Farrell et al. 2010), water treatment sludge/residuals (Van Rensburg and Morgenthal, 2003; Hsu and Hseu 2011), sewage sludge (USEPA 2007; Tamanini et al. 2008), composted sewage sludge (Van Herwijen et al. 2007). See Table 1 for the impact of selected waste amendments on plant yield and yield parameters. 
Lanning and Williams (1981) reported that nitrogen supply is a major limiting factor in reclamation schemes. Bradshaw (1983) recommended that a nitrogen capital of 1500 $1600 \mathrm{~kg} \mathrm{ha}^{-1}$ must be accumulated in spoils or disturbed land to support ecosystem establishment. Karlen et al. (2003) also identified soil nutrients as among the indicators of soil quality. Bending et al. (1999) recommended that $45 \mathrm{tha}^{-1}$ and $50 \mathrm{t} \mathrm{ha}^{-1}$ of thermally dried or digested cake sewage sludge respectively would provide $1500 \mathrm{~kg}$ of nitrogen to support ecosystem establishment on contaminated sites.

We conducted a 30 days experiment to investigate the impact(s) of the nutrient status and plant growth on contaminated soil amended with source-segregated green waste compost and water treatment sludge, thus enabling revegetation. The following hypotheses were tested:

1. Waste amendments can improve fertility (and nutrient status) of contaminated soils.

2. Water treatment sludge and green waste compost are suitable amendments in contaminated sites.

3. Nutrient levels from waste amendments are sufficient to promote crop growth.

4. Reed canary grass and white mustard can establish under such conditions and help to release nutrients.

The interesting component of this study is that, many studies conducted on the revegetation of amended contaminated sites have focused more on vegetation growth and bioavailability of the toxic compounds. However, few studies have taken time to also look at nutrient status and their availability in an amended contaminated soil. This study therefore assessed nutrient status of the amended contaminated soil, in addition to vegetation growth and heavy metal concentration. Furthermore, the two test plants (reed canary grass and white mustard) are among the potential bio energy crops in Europe (Tuck et al. 2006). Therefore, findings from this study may open doors for further research into growing bio energy crops on contaminated land. 


\section{Materials and Methods}

\section{Contaminated soil and waste amendments}

The grey silt loam [sand (28\%); silt (66\%); clay (6\%)] calcareous contaminated soil used in this study was collected from a former industrial site that has hydrocarbon contamination, and heavy metal contamination was also reported. The company had ceased operation and it was undergoing demolition prior to remediation as at the time of this study. Site clearance work and ground remediation of the site for a generic commercial/industrial end use was being carried out using ex-situ bioremediation. The contaminated soil was collected from an unamended pile of soil from the warehouse where the remediation was to be carried out. Green waste compost (PAS100) was obtained from MEC Recycling Lincolnshire and water treatment sludge cake from a local water treatment company. The green waste compost is processed using the windrow composting system, which involves piling of waste in long narrow rows or piles (Chipula 2013). The physicochemical analysis of the contaminated soil and the waste amendments are presented in Table 2. To investigate the optimum amount of green waste compost and water treatment sludge, application levels of: 0,90 and $180 \mathrm{t} \mathrm{ha}^{-1}$ (wet weight) was used in this study.

\section{Test Plants}

A commercial cultivar of reed canary grass (Phalaris arundinaceae L.) seeds were obtained from Advanta via the University of Teesside Middlesbrough, while the white mustard (Sinapis alba L.) seeds were obtained from Suffolk Herb, Essex. Reed canary grass had been reported to be able to survive on disturbed areas such as bergs and spoil-piles (USDA 2005). Few studies had also reported its revegetation on amended contaminated sites. Evanylo et al. (2005) reported that reed canarygrass remained persistent for 10 years after being planted on surface mine coal lands amended with a mixture of composted and dewatered, anaerobically digested biosolids at a rate of $368 \mathrm{Mg} \mathrm{ha}^{-1}$ dry weight. Similarly, Lord et al. (2007; 2010), reported that reed canarygrass showed good survival on contaminated soils and consistent 
growth rates in two subsequent seasons after being planted on brownfield land amended with green waste compost at 250, 500 and $750 \mathrm{t} \mathrm{ha}^{-1}$.

White mustard is a green manure crop; green manure crops are ploughed in to supply the soil with organic material, increase the availability of nutrients and trace elements, and increase soil biological activities (Schmid and Klay 1982). No previous study we were aware of had reported the use of white mustard in revegetating amended contaminated sites. Jolis (2009) reported that white mustard is not a heavy metal accumulator, while Lord et al. (2010) showed that reed canary grass is not a metal accumulator.

\section{Experimental design}

The combination of treatments is presented in Table 3. The experimental design is factorial, laid out in a randomised complete block. There were three factors which includes plants (reed canarygrass and white mustard), waste amendments (green waste compost - 42\% water content and water treatment sludge $-82 \%$ water content)] and application rates (0 t ha${ }^{1}$ (control), $90 \mathrm{t} \mathrm{ha}^{-1}$ and $180 \mathrm{t} \mathrm{ha}^{-1}$ ). Controls were planted but not amended. $90 \mathrm{t} \mathrm{ha}^{-1}$ indicate low application rate, while $180 \mathrm{t} \mathrm{ha}^{-1}$ indicates high application level. The treatments summed up to 10; each replicated 4 times thus making forty experimental units. The forty experimental units were arranged in 4 blocks, each block had one replicate of each treatment so as to minimize errors due to treatment arrangement.

\section{Establishment of pot experiment}

The pot experiment was carried out in the glass house facility of Cranfield University. A layer of gravel was placed in a 3 litre plastic pot with surface area $0.025 \mathrm{~m}^{2}$. Air dried contaminated soil (2.1 kg) sieved through a 2-mm metallic sieve was placed in plastic pots, occupying a depth of $12 \mathrm{~cm}$ above a layer of gravel to facilitate drainage. A $1.3 \mathrm{Mg} \mathrm{m}^{-3}$ bulk density was assumed because of the silty nature of the soil, following recommendations by Boyd (1995), in which the bulk density of mineral soil ranges from $1.3-1.5 \mathrm{Mg} \mathrm{m}^{-3}$, with the lower figure for fine surface soil. Having filled the pots with the contaminated soil, the soil was removed 
from each pot up to about two-third depth of the pot without disturbing the gravel and bulked with the amendments before returning the mixture back into the pots. The surface area of the pot was used to estimate the amount required for each pot. For an application rate of 90 and $180 \mathrm{t} \mathrm{ha}^{-1}$, we used $225 \mathrm{~g}$ and $450 \mathrm{~g}$ (wet weight) of the amendments respectively. Seeds of white mustard and reed canary grass were sown into the soil and covered lightly with soil.

Sopper and Seakers (1983) recommended that planting rates on contaminated soil are higher than the recommended rates used for non-contaminated soil so as to increase their germination percentage. Lewandowski et al. (2003) recommends a seeding rate of $15-20 \mathrm{~kg}$ ha ${ }^{-1}$ for reed canary grass grown as bioenergy crop. Similarly, Hall (2008) also recommends a seeding rate of $15.7 \mathrm{~kg} \mathrm{ha}^{-1}$ when seeded alone in pasture, hence, for this study; the seeding rate was increased because the grass was planted on contaminated soil. White mustard seeds were also planted at higher rates without special consideration to the rate since the seedlings were thinned to 8 best stands per pot. Watering was carried out manually using tap water, and this was not done to field capacity to avoid compaction due to heavy nature of the soil. The experimental blocks were rotated bi-weekly to compensate for possible uneven temperature of the glass house, and to minimise any environmental effect on the response. 15 days after the emergence of white mustards seedlings they were thinned down to the 8 best plants per pot. The growth period lasted for 30 days.

\section{Plant harvest and soil sampling}

At about 30 days growth period on the amended contaminated soil, white mustard showed signs of flowering hence, the experiments with white mustard were terminated and the plants were harvested. The soil surfaces were gently moistened to allow for easy removal of the plants from the soil. The plants were cleaned with deionised water so as to remove soil particles attached to them. The plants from each pot were placed into polythene bags and preserved in a refrigerator $\left(4^{\circ} \mathrm{C}\right)$ prior to laboratory analysis. 


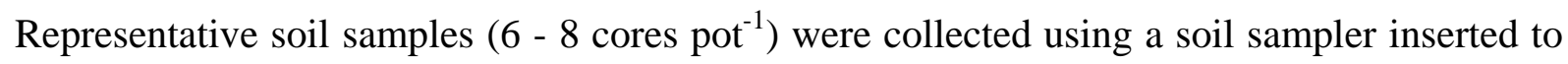
the base of the pot so as to have a representative sample of the whole soil layer. The collected soil from each pot was homogenised, placed in a polythene bag and stored in the refrigerator prior to laboratory analyses. Reed canarygrass was harvested four days after the harvest of white mustard because the seedlings of reed canarygrass emerged four days after the emergence of white mustard seedlings. The grasses were cut at $2 \mathrm{~cm}$ from the soil's surface, cleaned with deionised water, and preserved in the same way as for white mustard prior to laboratory analysis. Soils were collected using the same technique as for white mustard.

\section{Laboratory and statistical analysis}

Laboratory analyses were carried out using the Standard Operating Procedures (SOP) of the National Soil Research Institute (NSRI), Cranfield University. Soil particle sizes were determined in accordance with British Standard BS 7755 Section 5.4 (BS 1998a). Available nitrogen (total oxides of nitrogen and ammonium) were determined immediately after the collection of samples in accordance with method 53 of the MAFF Reference Book RB427 (BS 2001). Dry matter and water content on a mass basis were determined in accordance with the British Standard BS7755: Section 3.1(BS 1993). Organic matter was determined using a loss on ignition method in accordance with British Standard BS EN 13039 (BS 2000). Sample pH was determined in accordance with British Standard BS ISO 10390 (BS 2005). Cation exchange capacity was determined in accordance with the British Standard BS 7755 Section 3.12 (BS 1996). Total nitrogen was determined in accordance with British Standard BS EN 13654-2 (BS 2001). Total carbon and total organic carbon were determined in accordance with British Standard BS 7755 Section 3.8 (BS 1995a). Since the contaminated soil was calcareous, the total organic carbon of the soil was determined by titration methods in accordance with the British Standard BS 7755: Section 3.10 (BS 1995b). Available phosphorus was determined in accordance with the British Standard BS 7755: Section 3.6 (BS 1995c). Available potassium was determined in accordance with annexes D, E and G of the 
British Standard 3882 (BS 1994).Total phosphorus, total potassium and selected soluble trace elements (chromium, copper, lead and zinc) were determined in accordance with US EPA Method 3051 and British Standard BS 7755: Section 3.13 (BS 1998b). Statistical analyses were run in Minitab software from Minitab Inc, USA and charts were presented using Microsoft excel 2007. Data were checked for normality, and transformation was done when necessary before carrying out analysis of variance $(\mathrm{p}<0.05)$. Mean separation was evaluated using Tukey’s HSD.

\section{Results}

\section{Soil organic matter and total nutrients}

Application of the waste amendments improved the soil organic matter (OM), total nitrogen (TN), total phosphorus (TP), total potassium (TK) and carbon to nitrogen ratio (C: N) significantly $\mathrm{p}<0.05$ (Table 4). OM, TN, TK were higher in contaminated soil amended with green waste compost at $180 \mathrm{t} \mathrm{ha}^{-1}$ and lower in contaminated soil when amended with water treatment sludge at $90 \mathrm{t} \mathrm{ha}^{-1}$. C:N was lowest in green waste compost amended contaminated soil at $180 \mathrm{tha}^{-1}$.

\section{Available nutrients}

Soil nitrate $\left(\mathrm{NO}_{3}\right)$, available phosphorus (AP), available potassium (AK) and $\mathrm{pH}$ are presented in Figure 1. Soil ammonium in all of the treatments was below detection. Effects of waste amendment on $\mathrm{NO}_{3}, \mathrm{AP}, \mathrm{AK}$ and $\mathrm{pH}$ were significant $(\mathrm{p}<0.05)$. The available nutrients were higher in the contaminated soils amended with green waste compost at $180 \mathrm{t}$ ha ${ }^{-1} . \mathrm{NO}_{3}$ and $\mathrm{AP}$ showed a significant response with respect to plant type. $\mathrm{NO}_{3}$ was significantly higher in soil where reed canarygrass was grown while AP was significantly higher in soil where white mustard was grown.

Above ground dry mass, above ground tissue nutrient and heavy metal status 
Above ground dry mass (DM) were measured on per pot basis (Table 5). The mean DM were higher in the plants grown on amended contaminated soil than in the unamended contaminated soil. DM response to waste amendments was significant for white mustard, but insignificant for reed canary grass $(\mathrm{p}<0.05)$.

Tissue nutrients (mg g $\mathrm{g}^{-1}$ of plant) measurements included nitrogen, phosphorus and potassium (Figure 2). Response of plant tissue nutrient level to waste amendments and plant type showed significance $(\mathrm{p}<0.05)$. Higher level of tissue nutrients were observed in the plants grown on contaminated soil amended with green waste compost at $180 \mathrm{t} \mathrm{ha} \mathrm{h}^{-1}$. Plant nutrient levels are different for each plant, with reed canarygrass higher in $\mathrm{N}$ but white mustard higher in $\mathrm{K}$ and $\mathrm{P}$.

The test plants are not metal accumulators so heavy metal measurements were carried out only on the soil. After the 30 day growth period the heavy metals (Table 6) were not significantly $(\mathrm{p}<0.05)$ increased by the application of green waste compost and water treatment sludge. However, there was variation in the heavy metal loads, especially for $\mathrm{Cu}$, which may be related to variation within the source materials.

\section{Discussion}

After the 30 days trial in the screen house, the above ground dry mass yield of reed canarygrass and white mustard grown on amended contaminated soil increased by $120-222$ $\%$ and $130-337 \%$ respectively as compared to their controls. Improved vegetation growths for reed canarygrass on amended contaminated sites have been reported by (Evanylo et al. 2005; Lord et al. 2007; 2010; Jakubowski et al. 2013). Similar results were observed for shoot dry weight of rye grass, which increased by 13 and 3.2 times as compared to the unamended soil when heavy metal contaminated soil was amended with composted sewage sludge and green waste compost respectively at $20 \%$ ( $\mathrm{w} \mathrm{w}^{-1}$ compost/soil) (Van Herwijen et al. 2007). When green waste compost was applied at 0 and $40 \%\left(\mathrm{v} \mathrm{v}^{-1}\right)$ on highly acidic soil which was 
heavily contaminated with $\mathrm{Cu}$ and $\mathrm{Pb}$, the above ground biomass of Agrostis capillaries L. (colonial bentgrass) was significantly higher $(\mathrm{P} \leq 0.05)$ in green waste compost $(7.89 \mathrm{~g})$ than in unamended soil (1.58 g) (Farrell et al. 2010). Heil and Barbarick (1989) reported that application of ferric water treatment sludge at 5 and $10 \mathrm{~g} \mathrm{~kg}^{-1}$ resulted in 15 to $18 \mathrm{~g} \mathrm{pot}^{-1}$ of sorghum (sudan grass) as compared to $6 \mathrm{~g} \mathrm{pot}^{-1}$ in unamended soil. In this study it was notable that above ground dry mass of reed canary grass in the amended contaminated soils were not significantly different from the unamended. This may be associated with the ability of reed canarygrass to survive and remain persistent on disturbed soil. The non response of reed canary grass to waste amendment addition may be associated to the non-readily available chemical nitrogen in composts.

Perhaps unsurprisingly, the organic matter, total nitrogen, and total phosphorus contents of the amended contaminated soil were higher than in the unamended soil. Golabi et al. (2004) observed that soil organic matter was $34,46,54$, and $72 \mathrm{~g} \mathrm{~kg}^{-1}$ two months after land application of organic compost at: $0,75,150$, and $300 \mathrm{t} \mathrm{ha}^{-1}$ respectively. Similarly, in a study by Gregory and Vickers (2003), soil organic matter increased from $20 \mathrm{~g} \mathrm{~kg}^{-1}$ in the control to 50,60 , and $100 \mathrm{~g} \mathrm{~kg}^{-1}$ when municipal green waste material was applied at 25, 50 and $100 \mathrm{t} \mathrm{ha}^{-}$ ${ }^{1}$. Fowler et al. (2004) reported that cumulative nitrogen leaching was lower, ranging from 4.1-4.9 $\mathrm{kg} \mathrm{N} \mathrm{ha}^{-1}$ as compared to $8.4 \mathrm{~kg} \mathrm{~N} \mathrm{ha}^{-1}$ on fields with and without green manure. Nitrogen leaching under fallow conditions was higher (17\%) than when white mustard (3\%) was used as a catch crop (Merbach et al. 1997).

Nitrate was significantly higher $(\mathrm{p}<0.05)$ in this study in the amended contaminated soil sown with reed canarygrass as compared to that with white mustard. This might be related to a greater ability of the grasses to initiate nitrogen release. This is supported by the tissue nitrogen level of reed canarygrass being higher than that of white mustard. Gardner et al. (1983) reported that Lupinus albus (a green manure crop) was able to mobilise phosphorus in the soil through root exudates. Root exudates of white mustard also improved the phosphorus 
absorption of pea when they were grown in a mixture (Narwal 1998). This provides an explanation for the higher level of available phosphorus observed in the soil on which white mustard was grown, and hence higher tissue phosphorus level in white mustard as compared to reed canarygrass.

\section{Conclusions}

This study demonstrated the following findings:

1.Nutrient status of the contaminated soil increased via application of waste amendments, as shown by increasing soil organic matter content, total nitrogen, total phosphorus and reduced $\mathrm{C}: \mathrm{N}$ ratio.

2.Green waste compost improved the soil nutrient more than the water treatment sludge for the same application rate.

3.Reed canary grass and white mustard were able to grow on waste amended contaminated soils and they assisted nutrient release.

4.Dry mass yield increased by $120-222 \%$ and 130 - $337 \%$ in reed canary grass and white mustard respectively as compared to unamended soil

5.Application of green waste compost and water treatment sludge at $90 \mathrm{t} \mathrm{ha}^{-1}$ and $180 \mathrm{t} \mathrm{ha}^{-1}$ (wet weight) did not significantly increase soil heavy metal loads.

6.Reed canarygrass enhanced nitrogen release better than white mustard, while white mustard enhanced the release of phosphorus better.

This study showed that application of waste amendments was able to improve the nutrient status of contaminated soil, which in turned enhanced revegetation. The plant species grown, type of waste amendments and application rates all have significant effects on the nutrient status of amended contaminated soil. This study suggests that attempts at restoration or revegetation of contaminated sites should not just consider the bioavailability of toxic compounds but also the nutrient status and dynamics of the amended soils. 


\section{Acknowledgement}

The Authors sincerely appreciate Cranfield University and Association of Commonwealth Universities. Appreciation goes to technical staffs of Cranfield University soil science laboratory, and to Colin Hiscock, Bob Walker, Scott Baker and Pat Bellamy.

\section{References}

Bending NAD, McRae SG, Moffat AJ. 2008. Soil-forming materials: Their Use in Land Reclamation. London Stationary Office.

Boyd CE. 1995. Bottom soils, sediment, and pond aquaculture. Chapman and Hall. New York.

Bradshaw AD. 1983. The reconstruction of ecosystems. J Appl Ecol. 20:1-17.

BS (British Standard). 1993. Determination of dry matter and water content on a mass basis by a gravimetric method. BS 7755-3.1:1994 ISO 11465:1993. Soil quality. London, UK: British Standards Institution.

BS. 1994. Specification for Topsoil. BS 3882:1994, ISBN 058023406 1. London, UK: British Standards Institution.

BS. 1995a. Determination of organic and total carbon after dry combustion (elementary analysis). BS 7755-3.8, 1995. Soil quality. Chemical Methods. Equivalent to ISO 10694:1995. London, UK: British Standards Institution.

BS. 1995b. Determination of Carbonate Content (volumetric method). BS 7755-3.10, 1995. Soil quality. Chemical Methods. Equivalent to ISO 10693:1995. London, UK: British Standards Institution.

BS. 1995c. Determination of phosphorus- Spectrometric determination of phosphorus soluble in sodium hydrogen carbonates solution. BS 7755 Section 3.6, 1995. Equivalent to ISO 11263:1994. London, UK: British Standards Institution. 
BS. 1996. Determination of the potential cation exchange capacity and exchangeable cations using barium chloride solution buffered at $\mathrm{pH}=$ 8.1. BS7755: Section 3.12:1996. Soil Quality, Part 3, Chemical methods. ISO 13536: 1995. London, UK: British Standards Institution.

BS. 1998a. Determination of particle size distribution in mineral soil material. BS 7755 Section 5.4:1998 - Method by sieving and sedimentation which is identical to ISO 11277:1998. London, UK: British Standards Institution.

BS. 1998b. Determination of cadmium, chromium, cobalt, copper, lead, manganese, nickel and zinc in aqua regia extracts of soil. Flame and electro thermal atomic absorption spectrometric methods. BS 7755 Section 3.13, 1998. Soil quality. Chemical methods. Equivalent to ISO 11047:1998. London, UK: British Standards Institution.

BS. 2000. Determination of organic matter content and ash. BS EN 13039:2000, ISBN 0580 34253 0. Soil improvers and growing media. London, UK: British Standards Institution.

BS. 2001. Determination of nitrogen. Dumas method. BS EN 13654-2, 2001; Soil improvers and growing media. Equivalent to ISO 5725:1994. London, UK: British Standards Institution.

BS. 2002. Publicly available specification for composted materials - PAS 100. ISBN 0-58040590-7.2002. London, UK: British Standards Institution.

BS. 2005. Determination of pH. Soil quality. BS ISO 10390:2005. London, UK: British Standards Institution.

Chipula G. 2013. Optimising nutrient potential from compost and irrigation with wastewater to meet crop nutritional requirements. PhD Thesis, Cranfield University.

Chung RS, Wu SH. 1997. Effect of corncob compost on plant growth in an acid red soil. Commun Soil Sci Plant Anal. 28:673-683. 
Evanylo GK, Abaye AO, Dundas C, Zipper CE, Lemus R, Sukkariyah B, Rockett J. 2005. Herbaceous vegetation productivity, persistence, and metals uptake on a biosolidsamended mine soil. J Environ Qual. 34:1811-1819.

Farrell M, Jones DL. 2010. Use of composts in the remediation of heavy metal contaminated soil. J Hazard Mater. 175:575-582.

Farrell M, Perkins WT, Hobbs PJ, Griffith GW, Jones DL. 2010. Migration of heavy metals in soil as influenced by compost amendments. Environ Pollut. 158:55-64.

Fowler CJE, Condron LM, McLenaghen RD. 2004. Effects of green manures on nitrogen loss and availability in an organic cropping system. New Zeal J Agr Res. 47: 95-100.

Gardner WK, Barber DA, Parbery KG. 1983. The acquisition of phosphorus by Lupinus albus L. III. The probable mechanism by which phosphorus movement in the soil/root interface is enhanced. Plant Soil. 70:107-124.

Golabi MH, Denney MJ, Iyekar C. 2004. Use of composted organic wastes as alternative to synthetic fertilizers for enhancing crop productivity and agricultural sustainability on the tropical island of guam. In: Conserving Soil and Water for Society: Sharing Solutions. Proceedings of 13 th International Soil Conservation Organisation Conference; 2004 July 1; Brisbane, Australia.

Gregory AS, Vickers AW. 2003. The effects of a composted organic amendment on soil biological properties in a clay soil-forming material used as a landfill restoration cap. Land Contam Reclamat. 11:315-321.

Hall MH. 2008. Reed canary grass, Agronomy fact 26, 2008 . Available from: http://extension.psu.edu/plants/crops/forages/species/reedcanarygrass/extension_publication_file.

Harris JA, Birch P, Palmer JP. 1996. Land restoration and reclamation: Principles and Practice, Addison Wesley Longman, Limited, Harlow. 
Hartley W, Dickinson NM, Riby P, Lepp NW. 2009. Arsenic stability and mobilization in soil at an amenity grassland overlying chemical waste (St. Helens, UK). Environ Pollut. 157:2654-62.

Heil DM, Barbarick KA. 1989. Water treatment sludge influence on the growth of SorghumSudangrass. J Environ Qual.18:292-298.

Hsu WM, Hseu ZY. 2011. Rehabilitation of a sandy soil with aluminum-water treatment residual. Soil Sci. 176:691-698.

Jakubowski M, Stanisławska-Glubiak E, Gałka B. 2013. Usefulness of rock dust waste for the remediation of zinc contaminated soil. Environ. 24:1-4.

Jolis RP. 2009. Mobility of heavy metals in Mustard (Sinapis Alba. L) applied with sludge phytoconditioned product and biochar. MSc Thesis, Cranfield University.

Karlen DL, Ditzler CA, Andrews SS. 2003. Soil quality: Why and How? Geoderma 114:145156

Lanning S, and Williams ST. 1981. Nitrogen and Land Reclamation. Environ Pollut B. 2:179191.

Lewandowski I, Scurlock JMO, Lindvall E, Christou M. 2003. The development and current status of perennial rhizomatous grasses as energy crops in US and Europe. Biomass Bioenerg. 25:335-361

Lord RA, Atkinson J, Scurlock MO, Lane AN, Rahman PKSM, Connolly HE, Street G. 2007. Biomass, Remediation, re-Generation (BioReGen Life Project): Reusing brownfield sites for renewable energy crops. Proceedings of the 15th European Biomass Conference and Exhibition; 2007 May 7-11; Berlin. Germany.

Lord RA, Green R, Oyekanmi E, Atkinson J, Parry C, Bridgewood K. 2010. Green waste for greening brownfields: Using compost to establish energy crops on previously developed land. In: Fox HR, Moore HM, editors. Proceedings of British Land 
Reclamation Society Conference, Restoration and Recovery: Regenerating Land and Communities; 2000 September 7-9, University of Glamorgan, South Wales, UK.

MAFF-Ministry of Agriculture Fisheries and Food. 1986. Reference Book RB427: Analysis of agricultural materials. Methods No. 53, London: HSMO.

Mahdy AM, Elkhatib EA, Fathi NO. 2007. Drinking water treatment residuals as an amendment to alkaline soils: Effects on the growth of corn and phosphorus extractability. IJEST. 4:489-496.

Merbach W, Hoelzel D, Schalitz G, Pickert J, Jacob HJ, Latus C. 1997. Lysimeter Investigations on the Effect of Winter Catch Crops and Weeded Fallow on the NDynamics in a Sandy Treposol Soil of Northeast Germany. Isotopes Environ Health Stud. 33:53-59.

Narwal SS. 1988. Allelopathic interaction in multiple cropping systems. In Allelopathy in ecological agriculture and forestry. In: Narwal SS, Hoagland RE, Dilday RH, Reigosa MJ, editors. Proceedings of the III International Congress on Allelopathy in Ecological Agriculture and Forestry; 1998 August 18-21; Dharward, India.

Nathanail CP, Bardos RP. 2004. Reclamation of Contaminated Land. John Wiley \& Sons Ltd, The Atrium, Southern Gate, Chichester, West Sussex PO19 8SQ, England.

Norland MR, Veith DL. 1995. Revegetation of coarse taconite iron ore tailing using municipal solid waste compost. J Hazard Mater. 41:123-134.

Oh T, Nakaji K, Chikushi J, Park S. 2010. Effects of the Application of Water Treatment Sludge on Growth of Lettuce (Lactuca sativa L.) and Changes in Soil Properties. J Fac Agr Kyushu U. 55:15-20.

Schmid O, Klay R. 1982. The Principles and Practices of Green Manuring, in (ELM FARM RESEARCH CENTRE): Green Manures, Practical Handbook Series, Great Britain.

Sopper W, Seaker E. 1983. A guide for revegetation of mined land in the eastern United States using municipal sludge, Pennsylvania State University, University Park, PA. 
Tamanini CR, Motta ACV, Andreoli CV, Doetzer BH. 2008. Land reclamation recovery with the sewage sludge use. Braz Arch BioL Tech. 51: 643-655.

Tuck G, Glendining MJ, Smith P, House JI, Wattenbach M. 2006. The potential distribution of bioenergy crops in Europe under present and future climate. Biomass Bioenerg. 30:183-197.

USDA-United States Department for Agriculture. 2005. Reed Canary Grass (Phalaris arundinacea). Available from: http://www.invasive.org/weedcd/pdfs/wow/reedcanary-grass.pdf.

USEPA-United States Environmental Protection Agency. 2007. The use of soil amendments for remediation, revitalization, and reuse. EPA 542-R-07-013. Available at: http://cluin.org/download/remed/epa-542-r-07-013.pdf.

Van-Herwijnen R, Hutchings TR, Al-Tabbaa A, Moffat AJ, Johns ML, Ouki SK. 2007. Remediation of metal contaminated soil with mineral-amended composts. Environ Pollut. 150:347-354.

Van-Rensburg L, Morgenthal TL. 2003. Evaluation of water treatment sludge for ameliorating acid mine waste, J Environ Qual. 32:1658-1668. 
Table 1. Effect of selected waste amendments on Plant yield and yield components

\begin{tabular}{|c|c|c|c|c|c|c|c|}
\hline \multirow[t]{2}{*}{ Waste amendment } & \multirow[t]{2}{*}{ Application rates } & \multirow[t]{2}{*}{ Plant } & \multirow[t]{2}{*}{ Plant Mass } & \multicolumn{3}{|c|}{ Total tissue nutrients } & \multirow[t]{2}{*}{ Source } \\
\hline & & & & $\mathrm{N}$ & $\mathrm{P}$ & $\mathrm{K}$ & \\
\hline $\begin{array}{l}\text { Water treatment } \\
\text { sludge }\end{array}$ & $0,25,50(\% \mathrm{w} / \mathrm{w})$ & Lettuce & $\begin{array}{l}3.1,14.9,15.5 \\
\text { (g/plant fresh weight) }\end{array}$ & $\begin{array}{l}\text { 1.8, 5.1, } 4.5 \\
\text { (\% dry matter) }\end{array}$ & $\begin{array}{l}0.5,0.8,0.5 \\
\text { (\% dry matter) }\end{array}$ & $\begin{array}{l}2.4,5.1,4.8 \\
\text { (\% dry matter) }\end{array}$ & Oh et al.2010 \\
\hline $\begin{array}{l}\text { Water treatment } \\
\text { sludge }\end{array}$ & $0,5,10,15,20,25(\mathrm{~g} / \mathrm{kg})$ & Sorghum- Sudangrass & $\begin{array}{l}\text { 5.5, } 15,15,15,15,12.5 \\
\text { (g/pot total dry matter) }\end{array}$ & $\mathrm{nm}$ & & $\mathrm{nm}$ & $\begin{array}{l}\text { Heil and } \\
\text { Barbarick } 1989\end{array}$ \\
\hline $\begin{array}{l}\text { Water treatment } \\
\text { residuals }\end{array}$ & $0,10,20,30,40(\mathrm{~g} / \mathrm{kg})$ & Corn & $\begin{array}{l}\text { 8.9, } 11.81,14.31,17.90, \\
17.24 \text { (g/pot total dry matter) }\end{array}$ & $\mathrm{nm}$ & $\begin{array}{l}\text { 1900, 2000, 2150, } \\
\text { 2300, } 750(\mathrm{mg} / \mathrm{kg})\end{array}$ & & $\begin{array}{l}\text { Mahdy et al. } \\
2007\end{array}$ \\
\hline $\begin{array}{l}\text { Water treatment } \\
\text { residuals }\end{array}$ & $0,5.0,7.5,10(\% \mathrm{w} / \mathrm{w})$ & Bahia grass & $\begin{array}{l}\text { 8.1, 16.2, 25.1, and } 23.2 \\
\text { (g/pot) }\end{array}$ & $\begin{array}{l}25,30,31,31 \\
(\mathrm{~g} / \mathrm{g})\end{array}$ & $19,25,23,22(\mathrm{~g} / \mathrm{g})$ & $\begin{array}{l}\text { 3.9,3.6,1.7, } 1.3 \\
\text { (g/g) }\end{array}$ & $\begin{array}{l}\text { Hsu and Hseu, } \\
2011\end{array}$ \\
\hline $\begin{array}{l}\text { Green waste } \\
\text { compost }\end{array}$ & $0,30(\% \mathrm{v} / \mathrm{v})$ & Miscanthus & $53.5,133.77$ (g/pot) & $\mathrm{nm}$ & $\mathrm{nm}$ & $\mathrm{nm}$ & Hartley 2009 \\
\hline $\begin{array}{l}\text { Green waste } \\
\text { compost }\end{array}$ & $0,40(\% \mathrm{v} / \mathrm{v})$ & Bent grass & $\begin{array}{l}\text { 1.58, } 7.58 \text { (g above ground } \\
\text { dry mass) }\end{array}$ & $\mathrm{nm}$ & $\mathrm{nm}$ & $\mathrm{nm}$ & $\begin{array}{l}\text { Farrell et al. } \\
2010\end{array}$ \\
\hline Corn cob compost & $0,5,10,20(\mathrm{~g} / \mathrm{kg})$ & Corn & $\begin{array}{l}\text { 6.19, } 7.54,8.07,16.73 \\
\text { (g/plant dry weight) }\end{array}$ & $\mathrm{nm}$ & $\begin{array}{l}\text { 8.11, 13.23, 13.54, } \\
36.15 \text { (mg-P/plant }\end{array}$ & nm & Chung 1997 \\
\hline
\end{tabular}

Notes: $\mathrm{N}$ = Nitrogen; $\mathrm{P}$ = Phosphorus; $\mathrm{K}$ = Potassium; $\mathrm{nm}$ = Not measured; $\mathrm{w} / \mathrm{w}$ = weight for weight; $\mathrm{v} / \mathrm{v}$ = volume for volume 

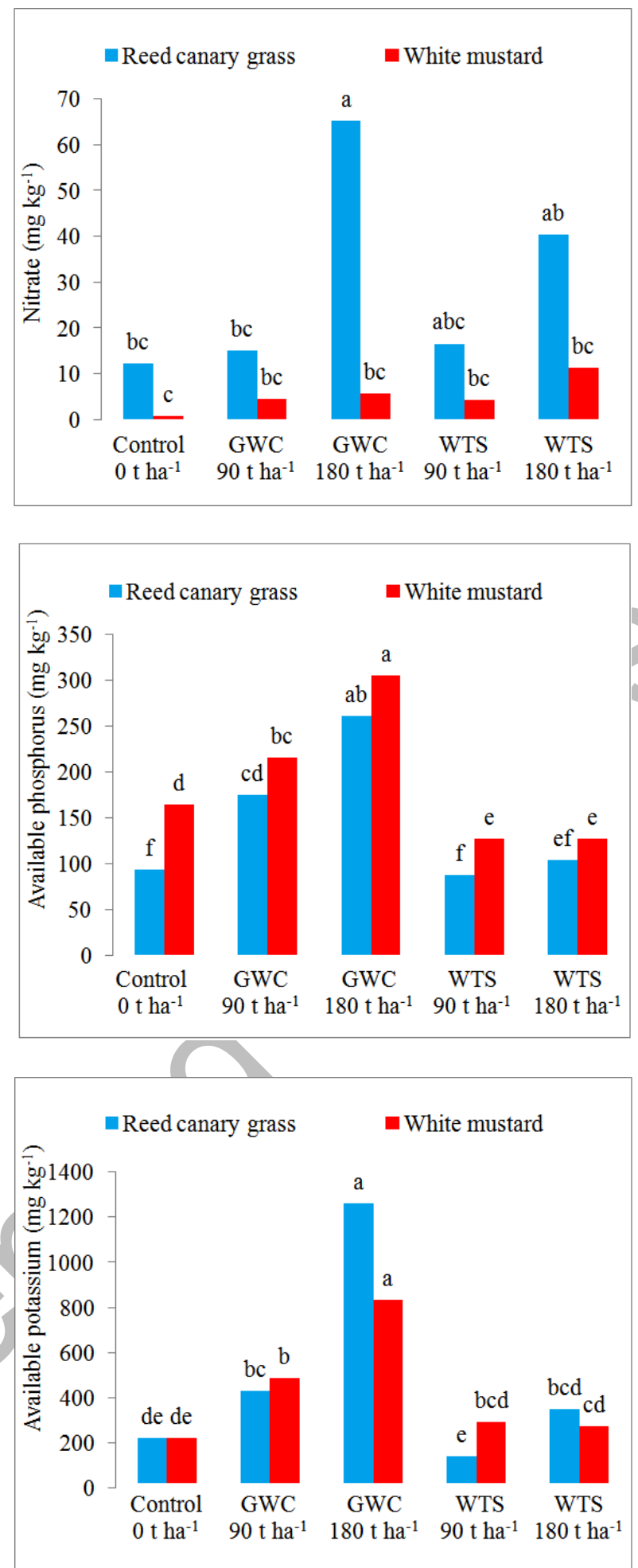

Figure 1. Effect of green waste compost (GWC) and water treatment sludge (WTS) on selected soil available nutrients after 30 days growth period of reed canary grass and white mustard. $(\mathrm{n})=4$; alphabets $=$ statistic difference $(\mathrm{p}<0.05)$ 

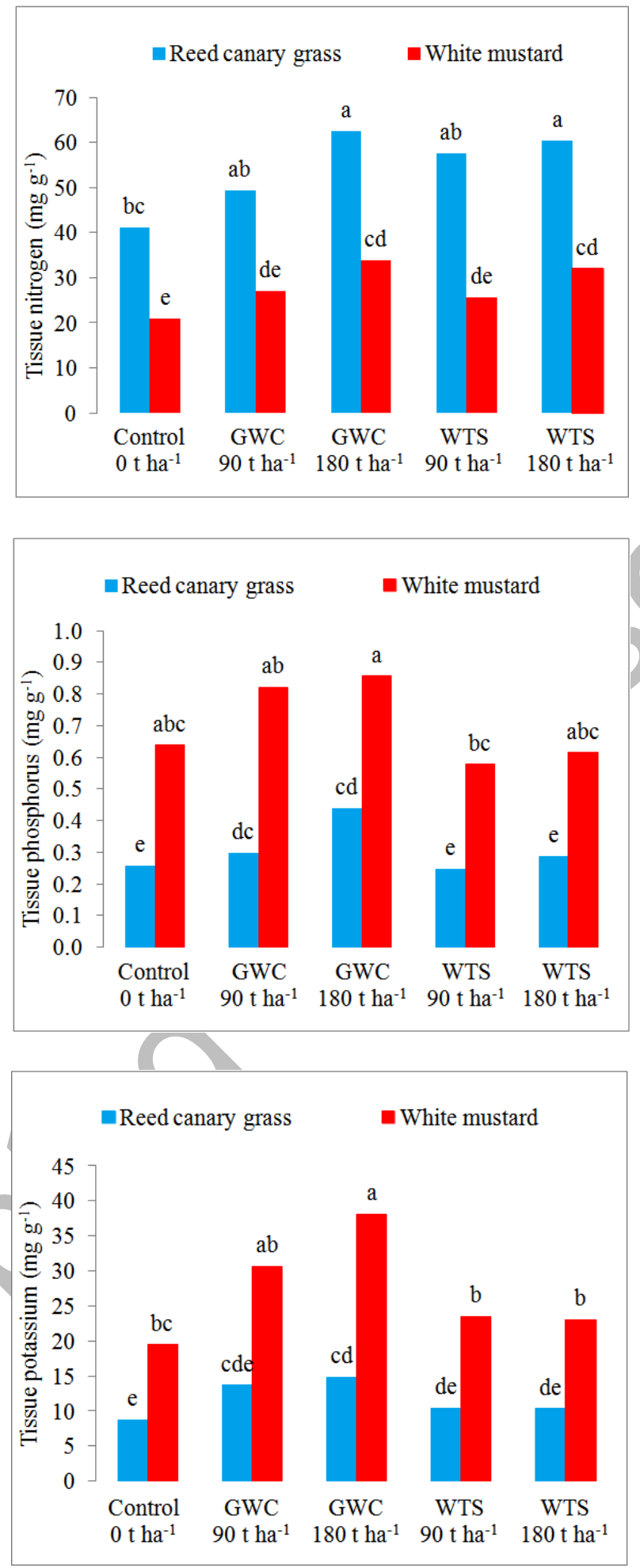

Figure 2. Effect of green waste compost (GWC) and water treatment sludge (WTS) on selected plant tissue nutrients after 30 days growth period of reed canary grass and white mustard. $(\mathrm{n})=4$; statistic difference $(\mathrm{p}<0.05)$ 